\title{
Elective induction of labour and caesarean section in low-moderate risk nulliparous women: a retrospective cohort study
}

\author{
Sarah Butler ${ }^{1}$, Euan Wallace ${ }^{2}$, Andrew Bisits ${ }^{3}$, Roshan Selvaratnam², and Mary-Ann \\ Davey $^{2}$
}

${ }^{1}$ Monash University Faculty of Medicine Nursing and Health Sciences

${ }^{2}$ Monash University

${ }^{3}$ University of New South Wales

December 13, 2021

\begin{abstract}
Objective: To evaluate whether elective induction of labour (eIOL) influences the rate of caesarean birth in uncomplicated pregnant women at term, compared to expectant management. Design: Retrospective cohort study. Setting: Births in Victoria between 2010 and 2018. Population: Term, singleton, vertex births from low-moderate risk pregnancies (n=396,164). Methods: Preliminary analyses compared eIOL at 37 weeks with expectant management both beyond that gestational age (preliminary analysis I) and at that gestational age and beyond (preliminary analysis II). Similar comparisons were made for eIOL at 38 , 39, 40 and 41 weeks' gestation and expectant management. The primary analysis repeated these comparisons, limiting the population to nulliparous women whose recorded indication for induction did not include one of a specified list of conditions. Chisquare tests and multivariable logistic regression were used. Adjusted odds ratios and $99 \%$ confidence intervals were reported. $\mathrm{P}<0.01$ denoted statistical significance. Main Outcome Measures: Unplanned caesarean birth, perinatal mortality Results: The proportion of nulliparous, low-moderate risk women who underwent IOL [?]37 weeks' gestation in Victoria increased from $24.6 \%$ in 2010 to $30.0 \%$ in 2018 (p-value <0.001). eIOL in nulliparous women was associated with an increased odds of caesarean birth when performed at 38 (aOR 1.23((1.13-1.32)), 39 (aOR 1.31((1.23-1.40)), 40 (aOR 1.42((1.35-1.50)), and 41 weeks' gestation (aOR 1.43((1.35-1.51)). Perinatal mortality was rare in both groups and non-significantly lower in the induced group at most gestations. Conclusions: eIOL was associated with an increased odds of caesarean birth from 38 weeks' gestation and a decrease in the odds of perinatal mortality.
\end{abstract}

\section{Hosted file}

IOL_Manuscript_Butler.docx available at https://authorea.com/users/450942/articles/549194elective-induction-of-labour-and-caesarean-section-in-low-moderate-risk-nulliparouswomen-a-retrospective-cohort-study

\section{Hosted file}

Table 1.docx available at https://authorea.com/users/450942/articles/549194-electiveinduction-of-labour-and-caesarean-section-in-low-moderate-risk-nulliparous-women-aretrospective-cohort-study

\section{Hosted file}

Table 2.docx available at https://authorea.com/users/450942/articles/549194-electiveinduction-of-labour-and-caesarean-section-in-low-moderate-risk-nulliparous-women-aretrospective-cohort-study 


\section{Hosted file}

Table 3.docx available at https://authorea.com/users/450942/articles/549194-electiveinduction-of-labour-and-caesarean-section-in-low-moderate-risk-nulliparous-women-aretrospective-cohort-study

\section{Hosted file}

Table 4.docx available at https://authorea.com/users/450942/articles/549194-electiveinduction-of-labour-and-caesarean-section-in-low-moderate-risk-nulliparous-women-aretrospective-cohort-study 